\title{
СОВРЕМЕННАЯ ЭМПИРИЧЕСКАЯ АНТИБАКТЕРИАЛЬНАЯ ТЕРАПИЯ У БОЛЬНЫХ С ПОСЛЕОПЕРАЦИОННЫМ СТЕРНОМЕДИАСТИНИТОМ
}

\author{
Шафер Я. В., ассистент кафедры Хирургии сердиа, магистральных сосудов и детской \\ хирургии, Харьковской медицинской академии последипломного образования, \\ ГУ «Институт общей и неотложной хирургии им. В. Т. Зайцева» АМН Украины \\ 2. Харьков, Украина
}

DOI: https://doi.org/10.31435/rsglobal_ws/31032019/6410

\section{ARTICLE INFO}

Received: 20 January 2019

Accepted: 27 March 2019

Published: 31 March 2019

\section{KEYWORDS}

empirical antibacterial therapy, postoperative purulent sternomediastinitis.

\begin{abstract}
The use of antibacterial drugs in the complex treatment of postoperative purulent sternomediastinitis is a mandatory component of the treatment of this pathology. The outcome of the disease often depends on the effectiveness and timeliness of antibiotic therapy of postoperative sternomediastinitis. When choosing the means of empiric antibacterial therapy, it is necessary to count the etiological role of various microorganisms in the development of postoperative purulent sternomediastinitis. Local and regional data considering the sensitivity and resistance of pathogens should also be taken into account. The results of treatment were analyzed in 57 patients with postoperative sternomediastinitis who were treated in the department of thoracic surgery, the department of surgical infections, as well as in the cardiac surgery department of the State Institution «V.T. Zaycev Institute of General and Urgent Surgery» Academy of Medical Sciences of Ukraine between the years 2008 and 2018. We have studied the etiology of microorganisms, their sensitivity. The results of research show a necessity to include oxacillin, gentamicin, cyphran, ceftrioxon and also antymycotic preparation into the spectrum of empirical antibacterial therapy postoperative purulent sternomediastinitis in Kharkiv's region.
\end{abstract}

Citation: Шафер Я. В. (2019) Modern Aspect of Empirical Antibacterial Therapy in Patients with Postoperative Purulent Sternomediastinitis. World Science. 3(43), Vol.2. doi: 10.31435/rsglobal_ws/31032019/6410

Copyright: (C) 2019 Шафер Я. В. This is an open-access article distributed under the terms of the Creative Commons Attribution License (CC BY). The use, distribution or reproduction in other forums is permitted, provided the original author(s) or licensor are credited and that the original publication in this journal is cited, in accordance with accepted academic practice. No use, distribution or reproduction is permitted which does not comply with these terms.

Введение. Ежегодно в мире выполняется более миллиона операций на сердце с применением срединной стернотомии. Частота развития послеоперационных гнойных медиастинитов (ПГМ) при этом находится в диапазоне 0,23-3,8 \% (при общем уровне раневой инфекции 1-4,3\%). Фактически это означает, что ПГМ развивается не менее чем в 10000 пациентов в год [1]. Летальность при передних гнойных медиастинитах, которые развились после стернотомии, составляет по данным разных исследований от 11,5 до 39,4 \% [2]. Больные, перенесшие гнойный медиастинит после операций на сердце, имеют худшие показатели выживаемости в течение первых лет после операции [3].

Применение антибактериальных препаратов в комплексном лечении гнойного послеоперационного стерномедиастинита является обязательной составляющей терапии данной патологии $[4,5,6]$. От эффективности и своевременности антибактериальной терапии послеоперационного стерномедиастинита зачастую зависит исход заболевания $[3,4,5]$. Самой 
оптимальной считается назначение антибактериальной терапии согласно выявленной чувствительности $[4,6]$.

Сегодня назначение эмпирической антибактериальной терапии при лечении стерномедиастинита является актуальной. Для определения чувствительности микрофлоры к антибиотикам традиционными методиками требуется 3 - 5 суток. Поэтому от правильности построения эмпирической антибактериальной терапии может зависеть успех дальнейшего лечения больного [4, 7].

При выборе средств эмпирической антибактериальной терапии необходимо основываться на этиологической роли различных микроорганизмов в развитии гнойных послеоперационных стерномедиастинитов. Следует также учитывать локальные и региональные данные о чувствительности и резистентности возбудителей [9].

Данные исследований последних лет, касающиеся чувствительности микрофлоры, выявляемой при гнойных послеоперационных стерномедиастинитах в Харьковском регионе, в доступной литературе не было выявлено.

Цель исследования: Изучить данные об этиологии и чувствительности микрофлоры, выявляемой при гнойных послеоперационных медиастинитах в Харьковском регионе, и предложить с учетом этих данных схему эмпирической антибактериальной терапии.

\section{Материалы и методы исследования.}

В данном исследовании были проанализированы результаты лечения 57 больных с послеоперационным стерномедиастинитом, которые находились на лечении в торакальном отделении, отделении хирургических инфекций, а также в отделении кардиохирургии ГУ «Института общей и неотложной хирургии им.В.Т.Зайцева» АМН Украины с 2008 по 2018 год. Нами был изучен этиологический состав микроорганизмов, их чувствительность.

Чувствительность к антибактериальным средствам изучали дискодиффузионным методом. Полученные данные обработаны методом вариационной статистики.

Результаты исследования и обсуждения.

В наших наблюдениях превалировал Streptococcus pyogenes, он был высеян у $11(19,3 \%)$ пациентов. Самостоятельно микроорганизм высевался у 5 (8,8 \%) больных, в $6(10,5 \%)$ наблюдениях S. Pyogenes был выделен в ассоциациях. Его сочетание с E.coli 2 (3,5 \%) пациента, Candida albicans - 2 (3,5\%) больных. Выделение Streptococcus Pyogenes, Citrobac., Candida albicans наблюдалось в 1(1,75\%) наблюдении, Streptococcus Pyogenes, Staphylococcus aureus, дрожжеподобные грибы - 1 (1,75 \%) пациент.

Чувствительность Str. Pyogenes выявлялась к доксициклину, пенициллину, ампициллину, тетрациклину, линкомицину, офлоксацину, ципрофлоксацину, цефтриаксону, цефазолину, гентамицину, эритану. В 7 (12,3 \%) наблюдениях была отмечена чувствительность Str. Pyogenes к цефтриаксону. В данную группу вошли ассоциации Str. Pyogenes c S.aureus и E.coli, которые в наших наблюдениях также были чувствительны к цефтриаксону. В 5 (8,8 \%) случаях S. Pyogenes обладал чувствительностью к офлоксацину, а в 1 (1,75 \%) наблюдении отмечалась чувствительность к данному антибиотику в ассоциации Str. Pyogenes и E.coli. У 5 $(8,8 \%)$ больных выявлялась чувствительность к ципрофлоксацину и 4 (7\%) пациентов доксициклину. К остальным антибактериальным препаратам выявлены случаи единичной чувствительности данного возбудителя.

Pseudomonas aeruginosa была выявлена нами в 7 (12,3 \%) наблюдениях. Высевалась самостоятельно и обладала чувствительностью к цефтриаксону, амикацину, цифрану, меропенему, максипину, цефоперазону. В $5(8,8 \%)$ наблюдениях Pseudomonas aeruginosa обладала чувствительностью к цефтриаксону. У 4 (7\%) больных отмечена чувствительность к амикацину и цифрану. Сочетание чувствительности микроорганизма к цефтриаксону, отмечено у $3(5,3 \%)$ больных.

Staphylococcus epidermalis высевался так же у $7(12,3 \%)$ больных. В $4(7 \%)$ наблюдениях микроорганизм выявляли самостоятельно, у 3 (5,3\%) пациентов совместно с Candida albicans. Чувствительностью Staphylococcus epidermalis обладал к доксициклину, гентамицину, цефуроксиму, цифрану, полимексину, заноцину. Чувствительность к гентамицину отмечена в $3(5,3 \%)$ наблюдениях. К остальным антимикробным препаратам отмечена единичная чувствительность. 
Streptococcus pneumoniae определялся у $7(12,3 \%)$ пациентов. В монокультуре микроорганизм определялся в 4 (7\%) наблюдениях, у 3 (5,3\%) больных выделялся в составе ассоциаций. Streptococcus pneumoniae, Candida albicans - 2 больных (3,5\%), Streptococcus pneumoniae, Acinetobacter, N.hava, Candida albicans - $1(1,75 \%)$ пациент. Чувствительность Streptococcus pneumoniae была выявлена к оксациллину, ампициллину, амоксиклаву, клафорану, цефтриаксону, эритромицину, линкомицину, рифампицину, левомицетину, доксицеклину, цефалексину, ципрофлоксацину, рефлину, заноцину, мефоксину, тиенаму. В 4 (7\%) наблюдениях отмечена чувствительность к оксациллину и амоксиклаву, в $3(5,3 \%)$ посевах определена чувствительность к цифрану, ампициллину, клафорану. Чувствительность же к остальным антибиотикам - единичная.

Str. Viridans выявлен был у 4 (7\%) больных. У 1 (1,75\%) пациента определялась монокультура микроорганизма, у 3 (5,3\%) больных определялось сочетание Str. Viridans с Candida albicans. Пенициллин, оксациллин, амициллин, амоксиклав, эритромицин, левомицетин, тетрациклин, цифран, заноцин доксициклин, рифампицин, гентамицин, авелокс, цефалексин, цефазолин, цефтриаксон, цефоперазон, цефтазидим, цефепим, меропенем - это спектр чувствительности, который наблюдался в данной группе исследований. Во всех наблюдениях отмечалась чувствительность Str. Viridans к оксациллину и левомицетину. К цефтриаксону, цифрану, ампициллину чувствительность наблюдалась у $2(3,5$ \%) больных.

Str. Haemolyticus выделился при бактериологических посевах у $4(7 \%)$ пациентов. У 3 (5,3 \%) определялась монокультура, а у 1 (1,75 \%) пациента наблюдалось сочетание Str. Viridans c Candida albicans. Чувствительность определялась к пенициллину, оксациллину, ампициллину, гентамицину, эритромицину, линкомицину, рифампицину, тетрациклину, доксициклину, цефалексину, рефлину, цифрану, меронему. К оксациллину и ампициллину чувствительность наблюдалась у всех пациентов. К цифрану и доксициклину были чувствительны 3 (5,3 \%) больных. К остальным антимикробным препаратам имелась единичная чувствительность.

Klebsiella pneumoniae определялась также у 4 (7 \%) наблюдаемых. Сочетание Klebsiella pneumoniae c H. Parainfluensis выявлена при одном исследовании, остальные посевы монокультура. Гентамицин, норфлоксацин, тетрациклин, офлоксацин, ципрофлоксацин, клафоран, цифран, заноцин, мефоксин, тиенам - спектр чувствительности к антибиотикам, выявленный при бактериологических посевах Klebsiella pneumoniae. Преимущественно антибактериальные препараты имели единичную чувствительность. Только к гентамицину отмечена чувствительность у 2 (3,5 \%) больных.

Staphylococcus aureus был высеян у 3 (5,3 \%) больных виде монокультуры.

Во всех наблюдениях отмечалась идентичная чувствительность к эритромицину, рифампицину, цефтриаксону, цифрану.

Enterococcus faecalis выявлен у $3(5,3 \%)$ пациентов в виде монокультуры. Спектр чувствительности составили доксициклин, левомицетин, рифампицин, гентамицин, нетилмицин, амикацин, цефуроксим, цефотаксим, цефтриаксон, рефлин, клафоран, цифран, заноцин.

В. catarrhalis как монокультура была выделена у 3(5,3\%) больных. В одном наблюдении отмечалась чувствительность к гентамицину, во втором наблюдении к цефтазидиму, цефтриаксону.

У одного пациента была высеяна Escherichia coli с чувствительностью к доксициклину, гентамицину, ванкомицину, цефуроксиму, цефотаксиму, цефо-перазону. У 3 (5,3 \%) больных были выявлены дрожжеподобные грибы.

Среди изученных результатов бактериологического исследования у 17 (29,8 \%) больных при первичном посеве выявлялись ассоциации микроорганизмов. Candida albicans входила в состав 13 (22,8 \%) выделенных микробных ассоциаций.

Несмотря на то, что даже в видовой группе микроорганизмов мог определяться различный спектр антибактериальной чувствительности, были выделены антибиотики с наибольшим спектром воздействия на патогенную микрофлору: оксациллин - Str. pneumoniae, Str. Viridans, Str. Haemolyticus, гентамицин - Staphylococcus epidermalis, Escherichia coli, Klebsiella pneumoniae, цифран - Pseudomonas aeruginosa. Staphylococcus aureus, цефтриаксон Str. Pyogenes, Staphylococcus aureus. Учитывая же количество микробных ассоциаций выявленных с участием Candida albicans, а также выявление дрожжеподобных грибов, как в 
ассоциациях, так и самостоятельно необходимо включение соответствующих препаратов в эмпирическую антибактериальную терапию.

Выводы. Полученные результаты исследования свидетельствует о необходимости включения оксациллина, гентамицина, цифрана, цефтриаксона, а также антимикозных препаратов в спектр эмпирической антибактериальной терапии послеоперационного гнойного стерномедиастинита в Харьковском регионе. Данный подход к эмпирической антибактериальной терапии является перспективным направлением в консервативной терапии послеоперационного стерномедиастинита.

\section{ЛИТЕРАТУРА}

1. Бокерия JІ.А., Вольгушев В.Е., Сигаев И.Ю., Абдуллаев А.А., Абовян А.А., Казарян А.В. Непосредственные результаты реваскуляризации миокарда с использованием бимаммарных кондуитов // Грудная и сердечнососудистая хирургия, 2007. - № 1. - С. 9-16.

2. Milano C.A., Kesler K., Archibald N., Sexton D.J., Jones R.H. Mediastinitis after coronary artery bypass graft surgery. Risk factors and long-term- survival. Circulation. 1995, Oct. 15; 92(8):2245-51.

3. Abboud C.S., Wey S.B., Baltar V.T. Risk factors for mediastinitis after cardiac surgeiy. Ann. Thorac. Surg. $2004 \mathrm{Feb} ; 77(2): 676-83$

4. Березняков И.Г. Инфекции и антибиотики. - Х: Константа, 2004. - 448 с.

5. Лапач С.Н., Чубенко А.В., Бабич П.Н. Статистические методы в медико-биологических исследованиях с использованием Exel. - К.: МОРИОН, 2001. - 408 с.

6. Фогт П.Р., Хубулава Г.Г., Марченко С.П. и др. Элиминация стернальной инфекции в кардиохирургии. Методические рекомендации. СПб.: Б. Браун Медикал, 2012. 24 с.

7. Голуб А.В. Новые возможности профилактики инфекций области хирургического вмешательства. Клиническая микробиология и антимикробная терапия. 2011. № 13 (1). С. 56-66.

8. Upton A., Roberts S.A., Milsom P., Morris A.J. Staphylococcal post-sternotomy mediastinitis: five year audit. ANZ J Surgery. 2005. Apr; № 75 (4). P.198-203.

9. Baldwin RT, Radovancevic B, Sweeney MS, Duncan JM, Frazier OH. Bacterial mediastinitis after heart transplantation. The Journal of heart and lung transplantation: the official publication of the International Society for Heart Transplantation. 1991; 11:3:1:545-549. 